\title{
The Topping of Sugarcane
}

\section{Severiano Alers Alers and George Samuels ${ }^{1}$}

\section{INTRODUCTION}

Sugarcane when ready for harvest consists of both cane stalk and leaves. In many varieties the leaves are normally confined to a growing top of from about 8 to 12 green leaves; the older fully dead leaves below this usually absciss and fall to the ground. In some varieties, such as Puerto Rico 980, the mature cane consists of a stalk and a top of about 10 leaves, whereas, Barbados 37161 tends to hold the dead leaves all along the stalk.

The point where the top of the sugarcane stalk is cut off is an arbitrary one. Most cane growers and mill officials have very definite opinions regarding the best point for the topping of cane under the multitude of different conditions met with in the field, but these opinions differ very widely, and the facts upon which they are based seen somewhat indefinite.

If the grower is paid for his cane by tonnage only, his desire is to send as much weight to the mill as possible. He, therefore, wants his cane cut as close to the very top as possible. This high discard includes many of the short, immature intermodes, very low in sugar, but having weight to add to the tonnage yield. If the grower is paid for his cane on a basis of both tonnage and sucrose yield, his desire is to send to the mill not only cane tonnage, but also high-sucrose cane. He, therefore, wants his cane cut at some intermediate point at the top which will give him the best sugar yield and tonnage. The sugarcane mill is interested in receiving the highest sucrose content in the cane it grinds. The mill, therefore, wants the cane cut for a low discard further down from the top to avoid the white top of soft-immature nodes which are high in moisture and nitrogen, but contain little or no recoverable sugars.

The dilemma of where to top the sugarcane is, therefore, not an academic question, but one of practical economics. The topping problem becomes even more critical when the additional problems concerning the mechanical harvesting of sugarcane are considered, because the use of mechanical harvesters makes the choice of exactly where to top the sugarcane a matter of selecting a specific measurement in inches, and not an arbitrary site, determined by the worker as he cuts sugarcane with a machete.

This paper reports the results of the initial phase of the work done by the Agronomy and Horticulture Department of this Agricultural Experi-

${ }^{1}$ Assistant Agronomist and Agronomist, respectively, Agricultural Experiment Station, University of Puerto Rico, Río Piedras, P.R. The authors wish to thank Mr. Francisco González-Vélez and Mr. Enrique González-Tejera, Research Assistants in Agronnmy, for their help in collecting the field data. 
ment Station on the influence of height of topping on yields of sugar, and its economic benefits for six varieties.

\section{PROCEDURE}

Six cane varieties, P.R. 1028, P.R. 1016, P.R. 1013, P.R. 980, P.R. 975, and B. 4362, were utilized in the topping study. The varieties used were part of a time-of-cutting experiment planted at the Palmas Alta farm at Central Plazuela, Barceloneta, and at the Santa Rita farm, Guánica, of the Land Authority of Puerto Rico. The Central Plazuela experiment planted on a Coloso clay represents the humid cane-growing area, and the Guánica experiment planted on a Vayas silty clay loam represents the irrigated cane-growing area of Puerto Rico.

The varieties were planted on plots with four rows 5 feet apart and 22 feet long, or about $1 / 100$ acre. Each variety was replicated six times. Both experiments were planted in August 1959. Two replications of each variety were harvested at 18 months of age in January 1961, and, thereafter, every 2 months until an age of 22 months. In May 1962 four replications of each variety were harvested at 12 months of age from the ratoon crop. Two topping treatments were utilized in this study.

"High topping" consisted of cutting the top cane leaves from the stalk at a point near the spindle (fig. 1). This manner of topping is normally practiced by the sugarcane cutters in Puerto Rico today. Such topping does not eliminate from the cane sent to the mill much of the white meristematic tissue associated with the "white nodes" and spindle. A few inches of leaf sheath are also left on the stalk.

"Low topping" consisted of cutting the top cane leaves from the stalk at a point approximately below the tenth node, the node enclosed by the tenth cane leaf from the top (fig. 1).

Ten whole canes were taken at random from each plot for each topping treatment. The canes were weighed after topping and then analyzed for sucrose in the mill of the Main Station at Rio Piedras.

To evaluate the economics of each topping method, the tonnage of cane and sugar per acre was calculated for each variety, using both the highand low-topping harvesting methods. The profit or loss received per ton of cane for the topping treatments were then calculated for each variety by arbitrarily assigning a value of $\$ 120$ per ton of sugar produced, and $\$ 2$ per ton for cutting, loading, and transporting the cane to the mill.

\section{RESULTS}

The profits or losses received per ton for the six varieties when harvested by low topping as compared with the regularly used high topping are given in table 1. 
In general, the averages for all varieties showed that low topping of sugarcane was profitable as compared with the high, or the normally used commercial topping, with the exception of cane at Guánica at 22 months. There were differences for varieties and age of cane.

P.R. 975 showed a profit from low cutting for all ages and both sites,

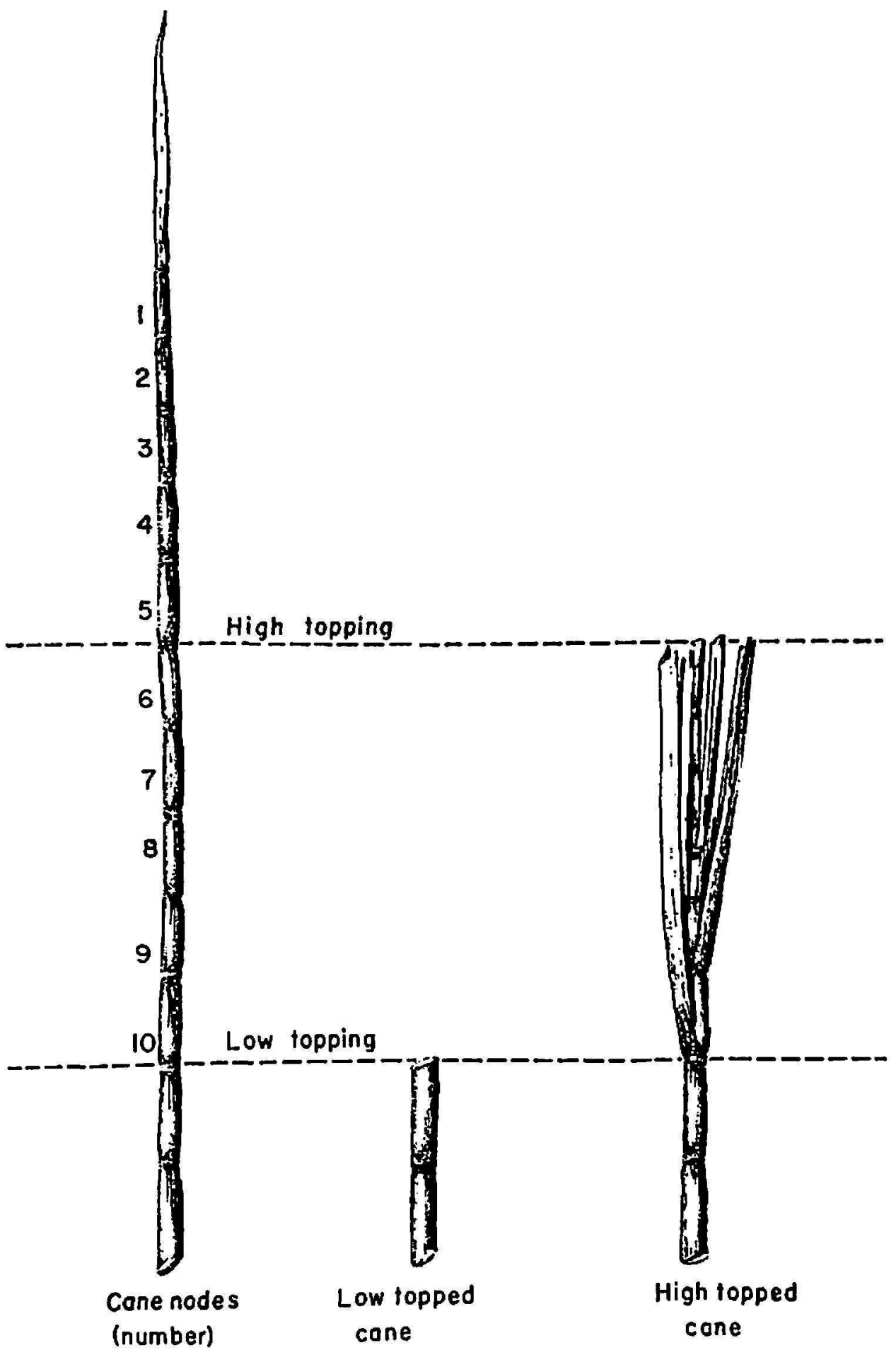

Fig. 1.-Relationship between low and high topping on the sugarcane stalk. 
TABLE 1.-The profit per ton of cane, increase in sucrose-percent-cane, and decrease in cane tonnage obtained for 6 sugarcane varieties at differenl age levels when comparing low with high topping of sugarcane

\begin{tabular}{|c|c|c|c|c|c|c|c|}
\hline \multirow{2}{*}{$\begin{array}{c}\text { Age of } \\
\text { cane } \\
\text { (months) }\end{array}$} & \multirow{2}{*}{ Variety } & \multicolumn{2}{|c|}{ Profit per ton of cane } & \multicolumn{2}{|c|}{$\begin{array}{l}\text { Increases in sucrose- } \\
\text { percent-cane }\end{array}$} & \multicolumn{2}{|c|}{ Loss in cane weight } \\
\hline & & Plazucla & Guánica & Plazucla & Guánica & Plazuela & Guánica \\
\hline \multirow[t]{2}{*}{12} & $\begin{array}{l}\text { P.R. } 1028 \\
\text { P.R. } 1016 \\
\text { P.R. } 1013 \\
\text { P.R. 980 } \\
\text { P.R. } 975 \\
\text { B. } 4362\end{array}$ & $\begin{array}{r}\text { Dollars } \\
0.36 \\
-.41 \\
1.08 \\
-.34 \\
.89 \\
.67\end{array}$ & $\begin{array}{c}\text { Dollars } \\
-0.10 \\
.76 \\
.52 \\
.57 \\
0 \\
.79\end{array}$ & $\begin{array}{c}\text { Percent } \\
11 \\
3 \\
10 \\
3 \\
11 \\
11\end{array}$ & $\begin{array}{c}\text { Percent } \\
5 \\
8 \\
6 \\
7 \\
2 \\
10\end{array}$ & $\begin{array}{c}\text { Percen! } \\
10 \\
5 \\
6 \\
7 \\
6 \\
8\end{array}$ & $\begin{array}{c}\text { Percent } \\
6 \\
5 \\
4 \\
4 \\
3 \\
6\end{array}$ \\
\hline & Average & 0.38 & 0.43 & 8 & 6 & 7 & 5 \\
\hline \multirow{4}{*}{18} & $\begin{array}{l}\text { Least significant dif- } \\
\text { ference between } \\
\text { varieties at: } \\
\text { 5-percent level } \\
\text { 1-percent level }\end{array}$ & $\begin{array}{r}0.33 \\
.46\end{array}$ & $\begin{array}{r}0.45 \\
.61\end{array}$ & & & & \\
\hline & $\begin{array}{l}\text { P.R. } 1028 \\
\text { P.R. } 1016 \\
\text { P.R. } 1013 \\
\text { P.R. } 980 \\
\text { P.R. } 975 \\
\text { B. } 4362\end{array}$ & $\begin{array}{r}0.04 \\
.17 \\
.39 \\
.65 \\
.94 \\
.91\end{array}$ & $\begin{array}{r}-0.70 \\
1.54 \\
.78 \\
.61 \\
1.42 \\
1.36\end{array}$ & $\begin{array}{r}5 \\
\mathbf{6} \\
8 \\
6 \\
12 \\
11\end{array}$ & $\begin{array}{r}1 \\
14 \\
10 \\
7 \\
14 \\
13\end{array}$ & $\begin{array}{l}6 \\
6 \\
6 \\
4 \\
7 \\
7\end{array}$ & $\begin{array}{l}6 \\
6 \\
6 \\
4 \\
7 \\
6\end{array}$ \\
\hline & Average & 0.52 & 0.95 & 8 & 10 & 6 & 6 \\
\hline & $\begin{array}{c}\text { Least significant dif- } \\
\text { ference between } \\
\text { varieties at: } \\
\text { 5-percent level } \\
\text { 1-percent level }\end{array}$ & $\begin{array}{l}0.75 \\
1.07\end{array}$ & $\begin{array}{r}0.15 \\
.20\end{array}$ & & & & \\
\hline \multirow[t]{2}{*}{20} & $\begin{array}{l}\text { P.R. } 1028 \\
\text { P.R. } 1016 \\
\text { P.R. } 1013 \\
\text { P.R. } 980 \\
\text { P.R. } 975 \\
\text { B. } 4362\end{array}$ & $\begin{array}{r}-.64 \\
.03 \\
.10 \\
.15 \\
1.21 \\
1.19\end{array}$ & $\begin{array}{r}-0.44 \\
-.28 \\
-.53 \\
.76 \\
1.11 \\
1.04\end{array}$ & $\begin{array}{r}4 \\
7 \\
5 \\
4 \\
15 \\
13\end{array}$ & $\begin{array}{r}2 \\
-2 \\
-4 \\
5 \\
8 \\
9\end{array}$ & $\begin{array}{r}10 \\
6 \\
5 \\
6 \\
8 \\
6\end{array}$ & $\begin{array}{l}\mathbf{5} \\
\mathbf{3} \\
\mathbf{3} \\
\mathbf{3} \\
\mathbf{3} \\
\mathbf{4}\end{array}$ \\
\hline & Average & 0.45 & 0.28 & 8 & 3 & 7 & 3 \\
\hline
\end{tabular}


TABLE 1.-Concluded

\begin{tabular}{|c|c|c|c|c|c|c|c|}
\hline \multirow{2}{*}{$\begin{array}{c}\text { Age of } \\
\text { cane } \\
\text { (months) }\end{array}$} & \multirow{2}{*}{ Variety } & \multicolumn{2}{|c|}{ Profit per ton of cane } & \multicolumn{2}{|c|}{$\begin{array}{l}\text { Increases in sucrose- } \\
\text { percent-cane }\end{array}$} & \multicolumn{2}{|c|}{ Loss in cane weight } \\
\hline & & Plazuela & Guánica & Plazuela & Guánica & Plazuela & Guánica \\
\hline \multirow{4}{*}{22} & $\begin{array}{c}\text { Least significant dif- } \\
\text { ference between } \\
\text { treatments at: } \\
\text { 5-percent level } \\
\text { 1-percent level }\end{array}$ & Dollars & $\begin{array}{l} \\
0.87 \\
1.23\end{array}$ & Percent & Percent & Percent & Percent \\
\hline & $\begin{array}{l}\text { P.R. } 1028 \\
\text { P.R. } 1016 \\
\text { P.R. } 1013 \\
\text { P.R. } 980 \\
\text { P.R. } 975 \\
\text { B. } 4362\end{array}$ & $\begin{array}{c}0.21 \\
-.36 \\
0 \\
1.21 \\
1.68 \\
.13\end{array}$ & $\begin{array}{r}-0.58 \\
-.86 \\
-.19 \\
-.37 \\
1.79 \\
-.62\end{array}$ & $\begin{array}{r}9 \\
5 \\
4 \\
12 \\
18 \\
4\end{array}$ & $\begin{array}{r}1 \\
-2 \\
2 \\
3 \\
13 \\
2\end{array}$ & $\begin{array}{l}8 \\
8 \\
5 \\
5 \\
8 \\
3\end{array}$ & $\begin{array}{l}5 \\
2 \\
4 \\
4 \\
4 \\
4\end{array}$ \\
\hline & Average & 0.46 & 0.14 & 9 & 3 & 6 & 4 \\
\hline & $\begin{array}{l}\text { Least significant dif- } \\
\text { ference between } \\
\text { treatments at: } \\
\text { 5-percent level } \\
\text { 1-percent level }\end{array}$ & $\begin{array}{l}0.77 \\
1.09\end{array}$ & $\begin{array}{l}0.35 \\
1.20\end{array}$ & & & & \\
\hline
\end{tabular}

with the exception of cane at Guanica at 12 months, where there was neither profit nor loss (table 1). The profit realized from low topping with P.R. 975 increased with the age of the cane harvested. For the humid cane area of Plazuela, the profit ranged from 89 cents per ton of harvested cane to $\$ 1.68$ per ton at 22 months of age. The irrigated cane at Guánica ranged from no profit at 12 months to $\$ 1.79$ per ton of cane harvested at 22 months.

B. 4362 gave significant profits from low topping at all ages and sites except at 22 months (table 1). B. 4362 profits from low cutting tended to increase with age of cane for the first three cutting ages at Plazuela, and the first two at Guninica; thereafter there was a dccrease as the cane grew older.

P.R. 980, the most widely planted variety in Puerto Rico, did not show a profit from low topping $v s$. high topping, except for the 12- and 18-month cane at Guánica and the 22-month at Plazuela.

P.R. 1013 at Plazuela had decreasing profits from low topping as the age of the cane increased, ranging from $\$ 1.08$ per ton of cane at 12 months to zero at 22 months. At Guánica this variety gave a profit for low topping at 12 and 18 months, but not at 20 and 22 months. 
P.R. 1016 gave variable results both for age and location. Low topping was not profitable at Plazuela. Good profits were realized for 12 and 18 months at Guánica.

P.R. 1028 showed losses from low topping at Plazuela and at Guánica as compared with high topping at harvest.

The question as to why low topping as compared with high topping produces profit in some cases and not in others can best be answered if we consider what the two harvesting methods accomplish. Low topping eliminates a portion of the sugarcane stalk which consists of immature nodes of white meristematic tissue and some portions of green sheath and leaf. This material is low in sucrose, for it is the active growing portion of the cane stalk. This means that the grower is paying money for the loading and transportation to the mill of a low to almost a nonsugar-containing material instead of high-sucrose sugarcane. If the portion of cane discarded in low topping does not weigh so much as to reduce cane tonnage markedly, and is extremely low in sugars, a profit, will be realized from low topping because of increases in sucrose-percent-cane in the milled cane.

Should the discarded material from low topping be high in sugars and weigh sufficient, leaving it in the field will mean a loss to the farmer.

The percentage increases in the sucrose content of the cane obtained by low topping as compared with high topping are presented in table 1. In all cases where high profits per ton of cane were realized from low topping, large increases were obtained in the sucrose-percent-cane also. Losses from low topping were associated with low or no sucrose increases. For example, at a cane age of 12 months at Guánica, P.R. 1028 and B. 4362 both lost 6 percent of cane tonnage. However, with a 10-percent increase of sucrosepercent-cane, a profit of 79 cents was realized for B. 4362 , whereas a loss of 10 cents was found for the P.R. 1028 for a sucrose-percent-cane increase of 5 percent.

Also presented in table 1 are the percentage losses in cane tonnage attributable to low $v s$. high topping. Perhaps not as drastic in its effects on profit as increases in sucrose, the smaller the loss in cane tonnage the larger the profits. For example at a cane age of 12 months, at Plazuela, P.R. 1028 and P.R. 975 both had an 11-percent increase in sucrose-percent-cane, but there was a profit of 36 cents for P.R. 1028 with a loss in cane of 10 percent, and, for P.R. 975, the profit was more than double, or 89 cents, when the cane-tonnage loss dropped to 6 percent.

Low topping of sugarcane is especially agreeable to the administration of the sugarcane factory, because the sugarcane being ground is higher in sucrose and lower in trash and in the nitrogen compounds that are usually found in the green top. Low topping $v s$. high topping presents a mixed blessing to the fieldman. There are savings in labor for loading, as some- 
what fewer tons per acre are produced with low topping. Yet low topping does mean some loss in cane tonnage per acre. If cane payments are on a tonnage and not on a sucrose-content basis this means a financial loss. However, in most cane areas of the world where sucrose as well as tonnage are used as bases of payment for cane sold to the factory, there are usually sufficient gains in savings from lower loading costs per acre and increased sucrose to make the low topping of sugarcane worth considering in the harvesting program.

\section{SUMMARY}

Experiments were undertaken to determine the influence of the height of topping of sugarcane at harvest on profits. Six cane varieties, P.R. 975, P.R. 980, B. 4362, P.R. 1013, P.R. 1016, and P.R. 1028, growing in both humid and irrigated areas of Puerto Rico were topped at harvested ages of $12,18,20$, and 22 months. Two heights of topping were used: High, at a point near the spindle, and low, at a point approximately below the tenth node. The results were as follows:

1. In general, low topping was more profitable than the high topping now in commercial use in Puerto Rico.

2. Low topping was most profitable for P.R. 975, which ranged from 89 cents per ton of harvested cane at 12 months to $\$ 1.68$ per ton at 22 months of age for the humid cane area, and from nothing at 12 months to $\$ 1.79$ per ton at 22 months of age for irrigated cane.

3. B. 4362, P.R. 980, and P.R. 1013 showed profit from low topping vs. high, with a few exceptions at certain ages.

4. P.R. 1016 gave variable results both for age and location, and P.R. 1028 showed only losses.

5. The reasons for profit or losses attributable to low or high topping are discussed, regarding as indicators the percentage increases in sucrosepercent-cane and losses in cane tonnage resulting from the topping methods.

\section{RESUMEN}

Se llevó a cabo una serie de experimentos para determinar el efecto de la altura a que se corta la caña al cosecharse sobre las ganancias. Se cortaron seis variedades, a saber, la P.R. 975, B. 4362, P.R. 980, P.R. 1013, P.R. 1016 y P.R. 1025, sembradas en terreno húmedo y bajo regadío, a los 12 , 18,20 y 22 meses de edad. Los cortes se hicieron a dos alturas distintas: un corte alto, cerca del cogollo, y uno bajo, cerca del décimo canuto. Los resultados fueron como sigue:

1. En general, el corte bajo resultó más lucrativo que el alto que es el que se acostumbra comercialmente en Puerto Rico.

2. El corte bajo fue más lucrativo cuando se usó en la variedad P.R. 975, fluctuando entre 89 centavos por tonelada de caña cosechada a los 12 
meses y $\$ 1.68$ a los 22 meses en terreno húmedo. En el caso de la caña sembrada en terreno bajo regadío la fluctuación fue entre cero a los 12 meses y $\$ 1.79$ a los 22 .

3. Las variedades B. 4362, P.R. 980 y P.R. 1013 reflejaron las ventajas del corte bajo al compararse con el alto, con muy pocas excepciones a ciertas edades.

4. La P.R. 1016 produjo resultados variables, tanto por edad como por la localidad, y la P.R. 1028 sólo reflejó pérdidas.

5. Se analizan los factores que causan ganancias o pérdidas atribuibles al corte bajo o alto, considerándose como índice el aumento en el porcentaje de sacarosa en la caña y las pérdidas en rendimiento causadas por el sistema de corte. 